\title{
The Constitutionality of the Exercise of Extraterritorial Powers by Municipalities
}

Thirty-five states currently have statutes in force authorizing some or all of their municipal subdivisions to exercise governmental powers beyond their corporate limits. These statutes characteristically allow controls over adjacent unincorporated areas by elected municipal officials without providing for participation in the election of those officials by the residents of the unincorporated areas.

Throughout the history of extraterritorial government, residents of unincorporated areas have challenged this exercise of governmental power without representation. Nearly all such challenges have failed. This comment reexamines the constitutionality of extramunicipal rule over unincorporated areas in light of modern equal protection doctrine in the area of voting rights.

\section{Current Extraterritorial Powers}

Authority for municipalities ${ }^{1}$ to exercise governmental powers outside their boundaries can be conferred only by the state. ${ }^{2}$ States that provide for "home rule" uniformly permit municipalities to govern only within their corporate limits unless the state legislature has expressly granted supplemental extraterritorial authority. ${ }^{3}$ States that concentrate authority in the state government enable municipalities to exercise only powers that are delegated to them by the state legislature. ${ }^{4}$ Under either theory of state government, extraterritorial powers exist only by virtue of particular statutory grants of power.

Extraterritorial government is usually justified on two grounds. ${ }^{5}$ First, a city can protect its own residents by extending its powers beyond its boundaries-for example, by zoning an unincorporated area abutting a single-family residential area for an identi-

' Theoretically, any municipal entity can be granted extraterritorial powers, but almost all such grants have been to cities. A notable exception is South Dakota's delegation of extraterritorial power to certain counties. See text and notes at notes 91-100 infra.

22 E. McQulluin, Municipal Corporations \I 10.07, at 751-52 (3d ed., rev. vol. 1966).

I Id. I 10.08, at 753-54.

I Id. II 10.09, at 754 .

s See, e.g., Anderson, The Extraterritorial Powers of Cities (pt. 1), 10 Minn. L. REv. 475, 475 (1926); Bouwsma, The Validity of Extraterritorial Municipal Zoning, 8 VAND. L. REv. 806, 807 (1955); Goodman, The Legal Basis of Extraterritorial Zoning in Oklahoma, 4 TuLSA L.J. 21, 22 (1967); Melli \& Devoy, Extraterritorial Planning and Urban Growth, 1959 Wis. L. Rev. 55,56 . 
cal or compatible use. A second justification for the use of extraterritorial powers is protection of extramunicipal residents. Without extraterritorial government, adjacent unincorporated areas might lack even the most elemental municipal services, such as police or fire protection.

A few states enable municipalities to exercise the full range of police power ${ }^{6}$ in adjacent unincorporated areas, but the majority delegate only some portion of the police power for extraterritorial exercise. The various delegations can be classified into five categories.

\section{A. 'Delegations of Full Police Powers}

Four states grant some or all of their cities complete police powers over abutting unincorporated areas. ${ }^{7}$ Idaho's statute, for example, empowers certain cities to control unincorporated areas within one mile of their corporate limits "in all matters . . . except taxation." North Dakota ${ }^{9}$ and South Dakota ${ }^{10}$ grant similar authority over areas within one-half and one mile, respectively, of city limits. In Alabama, unincorporated territory within as much as three miles of a city is subject to the city's "police jurisdiction.""1

\section{B. Regulatory Authority}

Many states permit their cities, or some of them, to exercise regulatory or prohibitory control over certain kinds of extramural activity. Most commonly, this kind of delegation empowers cities to prohibit or regulate offensive industries within a certain distance of the city limits. ${ }^{12}$ In some states, the statute suggests the kinds of

- In the major treatise on municipal corporations, McQuillin describes the police power as "the power to govern men and things," 6 E. McQuiluin, Municipal Corporations Tf 24.02, at 467 (3d ed., rev. vol. 1969) (citing Munn v. Illinois, 94 U.S. 113, 125 (1877)), and as the power to "govern the movement, acts, and words of persons and the use of things in the corporate area." Id.

' Ala. Code $\S 11-40-10$ (1975); Idaho Code $\S 50-606$ (1967); N.D. Cent. Code $\$ 40-06$ 01(2) (1968); S.D. CoMpILEd LAws ANN. § 9-29-1 (1967).

* Idaho Code $\S 50-606$ (1967).

' N.D. CENT. CODE $\$ 40-06-01(2)$ (1968) (granting power over areas within one-half mile of the city for enforcement of "police regulations and ordinances adopted to promote the peace, order, safety, and general welfare of the community").

in S.D. ComprLED LAws ANN. § 9-29-1 (1967) (granting power over areas within one mile of any city or city-owned public ground or park to exercise jurisdiction "for the purpose of promoting the health, safety, morals, and general welfare of the community").

"This jurisdiction extends a mile and a half beyond city limits if the city has a population under 6,000 , and three miles if the city's population is larger than 6,000. ALA. CODE $\S$ 11-40-10 (1975). See text and notes at notes 101-114 infra.

12 ARIz. Rev. Stat. \$ 9-240-B-21(c) (Supp. 1975); Del. Code tit. 16, $\$ 310$ (1974); Ill. 
activities it is intended to affect. For instance, the Arizona statute covers "slaughterhouses, tanneries, soap factories, establishments for the steaming or rendering of tallow, lard, or offal, and all other establishments or places where any nauseous, offensive, or unwholesome business may be carried on" within two miles of a city. ${ }^{13}$ Other states simply empower cities to suppress nuisances in certain areas, without providing any indication what is to be considered a nuisance. ${ }^{14}$

A different approach used in some states is to make ordinances on specified subjects applicable extraterritorially. Thus, four states grant extraterritorial authority over some aspects of land use, such as zoning or building codes, ${ }^{15}$ two permit the punishment of disorderly conduct (as defined by city ordinance), ${ }^{16}$ and two authorize municipal authorities to suppress prostitution. ${ }^{17}$

Four states grant their cities the power to license, regulate, or prohibit various forms of amusement beyond their borders. ${ }^{18}$ The Oregon statute even permits cities to hire the Portland Boxing and Wrestling Commission to regulate those activities. Once a city hires the Commission, its authority extends to the entire county in which the hiring city lies. ${ }^{19}$

Montana and Wyoming permit extraterritorial regulation of explosives, ${ }^{20}$ and Missouri still permits its cities to license

ANN. STAT. ch. 24, § 11-42-9 (Smith-Hurd 1962); IND. CodE ANN. § 18-1-1.5-6(d) (Burns 1974); Mont. Rev. Codes Ann. § 11-944 (1968); N.M. Stat. ANN. § 14-17-11 (1976); Utah Code ANN. $\S 10-8-66$ (1973); Wis. Stat. Ann. $\$ 66.052$ (West 1965 \& Supp. 1977). See also Mo. Ann. Stat. $\S 80.090(5)$ (Vernon 1952) (regulation of dram shops and places of amusement within onehalf mile of city limits).

13 Ariz. Rev. Stat. \$ 9-240-B-21(c) (Supp. 1975).

" Idaho Code § 50-334 (1967); Kan. Stat. § 13-1417 (1975); Md. AnN. Code art. 23A, § 2(23) (1973); Mich. Comp. Laws $\S 94.2$ (West 1967); Neb. Rev. Stat. $\$ 14-103$ (1974). See also WASH. Rev. CODE ANn. $\$ 35.22 .280(22)$ (1965).

15 Fla. Stat. AnN. $\S 163.175$ (West 1972) (city extraterritorial authority subject to agreement with county; "equitable representation" of extramural residents required on relevant commissions and boards); NEb. Rev. Stat. $\$ 16-901$ (1974); N.C. Gen. Stat. $§ 160 A-360$ (1976); Wis. Stat. ANN. § 62.23(2) (West 1957).

is Mo. AnN. Code art. 23A, \& 2(23) (1973); Mont. Rev. Codes AnN. § 11-927 (Supp. 1977).

17 Colo. Rev. Stat. $\S 31-15-401(1)$ (g) (Supp. 1975); Utah Code ANN. $\$ 10-8-41$ (1973).

18 Mo. ANN. Stat. $\$ 80.090(5)$ (Vernon 1952) (to license, regulate, or prohibit "public shows, circuses, theatrical and other amusements"); MoNT. REv. Codes ANN. $\S \S 11-918$ (including the power to "license, tax, and regulate circuses and shows of like character"), 11921 ("to regulate or prohibit dance houses"), and 11-973 (1968) ("to prevent and prohibit prize fights, boxing matches of any kind"); OR. REv. STaT. $\$ 463.120$ (1953) (to regulate boxing and wrestling); WASH. REv. CODE $\S 35.24 .2900$ (7) (1965) (to license "shows, exhibitions, and lawful games").

10 Or. Rev. Stat. $\S \S 463.115-120$ (1953).

${ }^{20}$ MoNT. Rev. CoDEs ANN. § 11-932 (1968) (storage of gunpowder, other explosives, tar, pitch, kerosene, oils, and turpentine may be regulated or prevented); WYo. STAT. $\$ 15.1-3(26)$ (1965) (storage or use of same may be prevented, restrained, or regulated). 
"dramshops and tippling houses" beyond their limits.."

\section{Health and Sanitary Regulations}

Eighteen states ${ }^{22}$ enable municipalities to exercise various degrees of control over health and sanitary conditions in nearby unincorporated areas. Thirteen states ${ }^{23}$ give city councils or boards of health chosen by city councils the power to create and enforce quarantine rules. A number of states provide for both extramural control of sanitary conditions and enforcement of quarantines. ${ }^{24}$

The general power to regulate health conditions encompasses the power to control pollution and refuse disposal. Wisconsin specifically empowers its cities to control areas "where refuse, rubbish, ashes or garbage shall be dumped . . . within one mile" of city limits. ${ }^{25}$ Another Wisconsin statute enables cities to "regulate or prohibit the emission of dense smoke . . . within . . . one mile" of its boundaries. ${ }^{26}$

Another aspect of the general power to control health conditions is the power to regulate or prohibit cemeteries near a city. ${ }^{27}$ Several of these cemetery statutes illustrate the obsolescence and bad draftsmanship that characterize many delegations of extraterrito-

${ }^{21}$ Mo. ANN. STAT. $\S 80.090(5)$ (Vernon 1952) (license, regulate, or prohibit dramshops and tippling houses).

22 ArIz. Rev. Stat. § 9-240-B-20(b) (Supp. 1975); Ark. Stat. AnN. § 82-204 (Repl. Vol. 1976); Colo. Rev. Stat. $§ 31-25-702$ (Supp. 1975); Idaho Code $\S 50-606$ (1967); Ill. ANn. Stat. ch. 24, § 7-4-1 (Smith-Hurd 1962); IND. Code § 18-1-1.5-7 (Burns 1974); Mrch. Comp. Laws § 94.1 (1967); Miss. Code ANN. § 21-19-3 (1972); Mont. Rev. Codes ANN. § 11-946 (1968); NeB. Rev. Stat. § 14-103 (1974); N.M. Stat. AnN. § 14-17-6(B) (1976); N.D. Cent. Code § 40-0601(2) (1968); Okla. Stat. ANN. tit. 11, § 666 (West 1959); Tex. Rev. Crv. Stat. ANn. art. 1015(2) (Vernon 1963); UtaH Code ANN. \$ 10-8-61 (1973); Wash. Rev. Code $\$ 35.22 .280(21)$ (Supp. 1975); Wis. Stat. ANN. \$ 66.052(2) (West 1965); Wyo. Stat. $\$ 35.377$ (1957).

27 Ariz. Rev. Stat. § 9-240-B-20(b) (Supp. 1975); Ark. Stat. ANN. § 82-204 (1976); Idaho CodE $\S 50-606$ (1967); ILl. ANN. STAT. ch. 24, § 7-4-1 (Smith-Hurd 1962); IND. Code $\S \S 18-1$ 1.5-6(d) \& 18-1-1.5-7(a), (c), (d), (e), (g), (h), (i), (j), (k) (Burns 1974); Mich. Comp. Laws $\S$ 94.1 (1967); Miss. Code Ann. $\$ 21-19-3$ (1972); Mont. Rev. Codes Ann. $\$ 11-946$ (1968); Nez. Rev. Stat. § 14-103 (1974); N.D. Cent. Code § 40-06-01(2) (1968); OkLa. Stat. Ann. tit. 11, $\S 666$ (West 1959); TEx. Rev. Civ. Stat. ANN. art. 1015(2) (Vernon 1963); Utah Code ANN. $\S$ 10-8-61 (1973).

24 See Idaho Code § 50-606 (1967) ("health or quarantine"); ILL. ANN. STAT. ch. 24, § 74-1 (Smith-Hurd 1962) ("health and quarantine"); N.D. CENT. CODE § 40-06-01(2) (1968) ("health and quarantine"); UTAH CODE ANN. $\$ 10-8-61$ (1973) ("health . . . and . . . quarantine").

${ }^{25}$ Wis. StaT. AnN. $\S 66.052(2)$ (West 1965).

${ }^{26}$ Id. $\$ 146.10$ (West 1974).

${ }^{27}$ Eight states specifically permit extraterritorial cemetery regulation. Colo. REv. STAT. $\S 31-25-702$ (Supp. 1975); INd. Code ANN. \$ 18-1-1.5-7(h) (Burns 1974); MoNT. REv. CodeS ANN. § 11-948 (1968); Neb. Rev. Stat. § 16-241 (1974); N.M. STAT. ANN. § 14-17-6 (1976); Utah Code AnN. § 10-8-62 (1973); Wash. Rev. Code ANN. $\S \S 35.22 .280(21), 35.23 .440(51)$ (1965); WYo. STAT. § 35.377 (1957). 
rial governing authority. Wyoming, for example, requires only that a cemetery be "near" a city to come within its jurisdiction, ${ }^{28}$ and Utah purports to grant its cities control over any cemetery in which their dead are buried. ${ }^{29}$

\section{Zoning Regulations}

Eighteen $^{30}$ or nineteen ${ }^{31}$ states permit some or all of their cities to zone adjacent unincorporated areas. Although these statutes differ, in every case the zoning power conferred is identical within and without the city limits.

A few statutes authorizing extramunicipal zoning provide for some representation of persons residing in the affected unincorporated area ${ }^{32}$ In Iowa, for example, two representatives of the unincorporated area must be appointed by the county board of supervisors to serve on the city planning commission if the city zones beyond the city limits. This attempt to provide some representation in the zoning process is rather half-hearted, however, because the county supervisors need not appoint the representatives until after the extraterritorial zoning ordinance has been drafted..$^{33}$ Furthermore,

2* Wyo. Stat. $\$ 35.377$ (1957). Nebraska has a law of similar effect. NEb. Rev. Stat. $\S$ 16-241 (1974).

2 Utah Code ANN. $\$ 10-8-62$ (1973). "[Cities] may . . . have and exercise police jurisdiction ... over any cemetery used by the inhabitants of the city ...." See also the Washington statute on the subject, WASH. REv. CODE $§ 23.440(51)$ (1965), granting to second class cities, as defined by WASH. REv. CODE $\S 35.01 .020$ (1965) as cities of not less than 10,000 in population, the power " $[t]$ o regulate the burial of the dead and to establish and regulate cemeteries, within or without the corporate limits . . .."

${ }^{30}$ Ariz. Rev. Stat. § 9-240-B-21(c) (Supp. 1975); ARK. Stat. Ann. § 19-2827 (1968); Fla. Stat. ANN. § 163.175 (West 1972); Idaho Code, § 67-6526 (Supp. 1977); Ill. Ann. Stat. ch. 24, § 11-31-1 (Smith-Hurd Supp. 1976); IND. CodE § 18-7-5-34 (Burns 1974); Iowa Code ANN. $\S 414.23$ (West 1976); Ky. Rev. Stat. § 100.131 (1970); Mich. Comp. Laws $\S 125.36$ (1976); Minn. Stat. Ann. $\$ 462.357$ (West Supp. 1976); Mont. Rev. Codes Ann. $\$ 11-2702(2)$ (Supp. 1975); Neb. Rev. Stat. $\S \S 16-901,14-418$ (1974); N.M. Stat. ANN. $\$ 14-20-2(B)$ (1976); N.C. Gen. Stat. § 160A-360 (1976); N.D. Cent. Code § 11-35-02 (1976); Tenn. Code ANn. § 6-609 (1971); W. VA. Code $\S 8-24-71$ (1976); Wis. STAT. ANN. $\S 62.23(7 a)$ (West Supp. 1976).

st A nineteenth, arguably, is South Carolina. Although no statute of the state explicitly grants cities the power to zone extraterritorially, one, S.C. CoDE $\S 5-23-580$ (1977), gives municipal planning commissions jurisdiction over subdivisions of all land within three miles of the municipality. A second, S.C. CoDE § 5-23-490 (1977), gives these planning commissions the power to include territory outside city limits in the master city plan. The commissions also have authority over the building of new streets in territory within three miles of the city limits. S.C. CODE $\$ 5-23-600$ (1977). The extraterritorial powers of the commissions are, however, limited by S.C. CODE $\$ 5-23-740$ (1977) solely to "the matter of planning and laying out new streets in new subdivisions."

32 Ariz. Rev. Stat. § 9-461.11(c) (Supp. 1975); Fla. Stat. AnN. § 163.175 (West 1972); Iowa Code Ann. \$ 414.23 (West 1976); Mont. Rev. Codes Ann. § 11-2702(2) (Supp. 1977); N.C. Gen. Stat. $\$ 660$ A-362 (1976).

is A municipality, during the time its zoning jurisdiction is extended under this 
appointment of two non-city representatives may not result in proportional representation of non-city interests. More importantly, the planning commission has only an advisory function; zoning ordinances must actually be enacted by the city council, on which residents of the unincorporated area are not represented. ${ }^{34}$ Other states' provisions for representation of non-city interests in the zoning process are similarly flawed..$^{35}$

\section{E. Platting and Subdivision Regulation}

Instead of or in addition to zoning regulation, twenty-four states require city approval for extramunicipal subdivisions or for platting extramunicipal land. ${ }^{36}$ These statutes typically require approval of a city agency before a landowner may subdivide or record a plat or property. In some states that agency is the planning commission; in others approval of the city council is required. ${ }^{37}$

The primary purpose of subdivision regulation appears to be prevention of fraud, ${ }^{38}$ but the effects of such regulation can be simi-

section, shall increase the size of its planning and zoning commission and its board of adjustment each by two members. The additional members shall be residents of the area outside the city limits over which the zoning jurisdiction is extended . . . .

Iowa CoDE ANN. $\$ 414.23$ (West 1976) (emphasis added).

34 See Iowa Code Ann. $\$ \S 414.4 \& 414.6$ (West 1976).

35 The statutory schemes of Arizona and Montana are similar to Iowa's, except that they provide for addition of two extramunicipal representatives to the planning council before the extramunicipal area is zoned. The problems of malapportionment and the council's advisory nature remain. Ariz. Rev. Stat. \& 9-461.11 (Supp. 1975); Mont. Rev. Codes ANn. § 11-2702(2) (Supp. 1976).

${ }^{36}$ Ala. Code $\S \S 11-52-30,11-52-31$ (1977); Ariz. Rev. Stat. § 9-474 (Supp. 1975); Colo. Rev. Stat. § 31-23-212 (Supp. 1975); Fla. Stat. ANN. \$§ 163.175(1), 177.071 (West 1972 \& Supp. 1976); Idaho Code $\$ 50-1360$ (1967); Ill. ANN. STAT. ch. 24, § 11-12-5(1) (Smith-Hurd 1962); IND. Code ANN. $\$ 18-7-5-47$ (Burns 1974); Iowa Code ANn. \$\$ 409.1, 409.7 (West Repl. Vol. 1976); Kan. Stat. § 12-705 (1975); Ky. Rev. Stat. \$ 100.131 (1970); Md. ANN. Code art. 66B, $\$ 5.01$ (1970); Mich. Comp. Laws ANn. $\$ \S 125.36,125.43$ (1970); Mont. Rev. Codes ANn. $\$ \S 11-2702(2), 3305$ (1968 \& Supp. 1975); Neb. Rev. Stat. $\$ 14-116$ (1974); N.M. Stat. ANN. \$14-18-5 (1976); N.C. Gen. Stat. \$ 160A-360 (1976); Ohio Rev. Code AnN. § 711.09 (Page 1976); OKLa. Stat. AnN. tit. 11, §1423 (West 1959); Or. Rev. Stat. § 227.110(1) (1975); S.C. CODE $\S \S 5-23-580,5-23-590$ (1977); S.D. CoMpiled LAws ANN. $\$ \S 11-3-6 \& 11-6-26$ (1967); TEX. Rev. Civ. Stat. ANN. art. 974(a) (Vernon 1963 \& Supp. 1976); W. VA. Code § 39-1-16 (1966); Wis. Stat. AnN. $\$ 236.10$ (b) (West 1957). The statutes of New Hampshire are ambiguous on whether extraterritorial plat or subdivision approval is authorized. Only power to include extramunicipal territory in master plans is specifically mentioned. N.H. REv. STAT. ANN. $\S \S$ 36-13, 36-19 (1970).

37 Fla. Stat. Ann. $\$ 177.071$ (Supp. 1976); Idaho Code $§ 50-1306$ (1967); Neb. Rev. Stat. $\S 14-116$ (1974); N.C. Gen. Stat. § 160A-360(b) (1976); S.D. Compiled Laws ANN. § $111-3-6$ \& 11-6-26 (1967); W. VA. Code § 39-1-16 (1966); WIs. STAT. ANN. § 236.10(b) (West 1957).

3* Bartelt, Extraterritorial Zoning: Reflections on its Validity, 32 Notre DAME LAw. 367, 394 n.89 (1957). See also Note, Land Subdivision Control, 65 HaRv. L. Rev. 1226, 1231 (1952). 
lar to the effects of zoning laws. ${ }^{39}$ A city may require, for example, that subdivided lots be of a certain minimum size, or may demand dedication of a percentage of the subdivided property for public parks, schools, or streets. In most states, no representation is afforded residents of the unincorporated area, although in those states which require representation on the city planning commission if the city exercises extraterritorial zoning power, the same commission also regulates extraterritorial subdivision and platting.

\section{F. Summary}

The five varieties of extraterritorial powers share several features. Each permits elected city officials to pass ordinances affecting areas outside their constituencies and thus denies residents of those areas any political representation in matters affecting them directly. In all instances the power wielded by the elected officials derives from the police power of the state and is supported by the power of municipal officials (usually city councils) to authorize fines or incarceration to ensure compliance. In short, each of the types of delegated police power involves the exercise of governmental power over citizens who have no political influence over the exercise of that power.

\section{Early Challenges to the Constitutionality of Delegations of Extraterritorial Powers}

Statutory schemes involving the delegation of extraterritorial police power to cities are not of recent origin; most of the enabling statutes have direct antecedents dating from the end of the last century. Until the latter part of the nineteenth century the power of state legislatures to delegate extraterritorial powers was unquestioned. ${ }^{40}$ Dillon's noted treatise on municipal corporations, first published in 1872, enunciated the central proposition-later known as "Dillon's Rule"-that cities are creatures of legislative convenience, whose powers and jurisdictions could be altered or destroyed by legislative action. ${ }^{41}$ Although some jurists, notably Judge Cooley, ${ }^{42}$ espoused the notion that Americans had an inherent or

31 Bartelt, supra note 38 at 394-96; Note, Land Subdivision Control, 65 HaRv. L. REv. 1226, 1227 (1952).

to See, e.g., Harrison v. Mayor \& City Council of Baltimore, 1 Gill 264 (Md. 1843) (upholding an ordinance with potential for extraterritorial application).

" J. Dillon, Municipal Corporations $\S 30$, at 71-73 (1st ed. 1872).

${ }^{42}$ See People ex rel. Le Roy v. Hurlbut, 24 Mich. 44, 98 (1871) (Cooley, J.); People ex rel. Park Comm'rs v. Common Council, 28 Mich. 228 (1873) (Cooley, J.). Cooley's position 
common-law right to self-government, the courts never accepted this view. ${ }^{43}$ Later scholarly treatment of municipal corporations also relied on the foundation laid by Dillon. In the first extensive work on extramunicipal powers, published in 1926, political science professor William Anderson agreed with Dillon and stated that cities, as agents of the state, may exercise such authority as the state chooses to delegate. ${ }^{44}$ Anderson articulated two additional arguments supporting delegation of extraterritorial powers: judicial rejection of Cooley's notion of an inherent right to self-government, ${ }^{45}$ and the implicit consent of non-city residents, through their representatives in the state legislature, to delegations of extraterritorial powers. ${ }^{46}$

The courts almost universally rejected challenges to the constitutionality of extraterritorial delegations. The first case to consider a due process challenge, Board of Trustees $v$. Watson, ${ }^{47}$ is fairly typical. In Watson, the Kentucky Court of Appeals rejected a claim that the imposition of a license fee on a liquor retailer by a town in which he neither resided nor voted deprived him of property without due process. ${ }^{48}$ The court held that because the state could validly exercise the police power over the sale of liquor, it could delegate that power "to the local government of the community immediately interested." "49 Subsequent due process challenges to extraterritorial regulation in other states also failed..$^{50}$

was shared by Judge Eugene McQuillin. In his influential treatise on municipal corporations, Judge McQuillin stated that the right to local self-government derived from unwritten "fundamental principles." 1 E. McQuiluin, Municipal CoRporations 70 (1st ed. 1911). But see 1 E. McQuiLlin, Municipal Corporations $\$ 1.42$ at 52 (3d ed., rev. vol. 1971): "[I]t seems that the doctrine of the existence of an inherent right of local self-government . . . does not at present exist, and according to some authorities never did exist in this country."

${ }^{13}$ See, e.g., Robb v. City of Indianapolis, 38 Ind. 49 (1871).

4 Anderson, The Extraterritorial Powers of Cities (pt. 2), 10 Minn. L. Rev. 564, 580 (1926).

${ }^{45}$ Id. at 580-81 (citing McBain, The Doctrine of an Inherent Right of Local SelfGovernment (pts. 1-2), 16 Colum. L. Rev. 190, 299 (1916)).

"I "If the consent of the governed is a prerequisite to a valid act of legislation, that consent has been given by the [non-city] voters' representatives in the legislature." Id. at 581.

More recent commentators have reiterated Anderson's rationales. See, e.g., Bartelt, Extraterritorial Zoning: Reflections on its Validity, 32 Notre DAME LAw. 367, 400-02 (1957); Bouwsma, The Validity of Extraterritorial Municipal Zoning, 8 VAND. L. Rev. 806, 814 (1955); Goodman, The Legal Basis of Extraterritorial Zoning in Oklahoma, 4 TurSA L.J. 21, 27 (1967). Goodman seems also to suggest that the public would revolt if delegations of unreasonable extraterritorial powers were made, and that the absence of such a revolt currently evidences the eminent reasonableness and constitutionality of existing delegations. Id. at 27-28.

$1768 \mathrm{Ky}$. (5 Bush) 660 (1869).

13 The claim was based on the due process clause in the state constitution.

10 $68 \mathrm{Ky}$. at 662 .

so See, e.g., White v. City of Decatur, 225 Ala. 646, 144 So. 873 (1932) (challenging 
The cases did suggest, however, a single due process limitation on extraterritorial governance. Beginning with the Watson case, ${ }^{51}$ courts drew a distinction between the extraterritorial imposition of license fees, which was permissible, and extraterritorial taxation, which was not. ${ }^{52}$ The distinction was usually justified on the ground that taxes benefit only the town, whereas licensing and license fees benefit extraterritorial residents as well. ${ }^{53}$

In only one major case did a court strike down a delegation of extraterritorial powers on due process grounds. In Malone $v$. Williams ${ }^{54}$ Tennessee's highest court invalidated a statute that replaced the major elected officials of the city of Memphis with legislative appointees and gave the appointees vastly increased extraterritorial powers. ${ }^{55}$ The Malone court added a limiting gloss to tradi-

extraterritorial business license tax); Jordan v. City of Evansville, 163 Ind. 512, 72 N.E. 544 (1904) (liquor regulation); Schlientz v. City of North Platte, 172 Neb. 477, 110 N.W.2d 58 (1961) (zoning); State v. Rice, 158 N.C. 635, 74 S.E. 582 (1912) (sanitary regulations); City Transportation Co. v. Pharr, 186 Tenn. 217, 209 S.W.2d 15 (1948) (regulation of a bus line); Walworth County v. City of Elkhorn, 27 Wis. 2d 30, 133 N.W.2d 257 (1965) (zoning). In each case the court held that the challenged statutory scheme did not violate the constitutional guarantees of due process.

$5168 \mathrm{Ky}$. (5 Bush) 660 (1869).

32 See, e.g., Atlantic Oil Co. v. Town of Steele, 283 Ala. 56, 214 So. $2 d 331$ (1968); City of Prichard v. Richardson, 245 Ala. 365, 17 So. 2d 451 (1944); Wells v. City of Weston, 22 Mo. 384 (1856). See also Patterson v. City of Naperville, 9 Ill. 2d 233, 137 N.E.2d 371 (1956), in which the court upheld enforcement of extraterritorial subdivision regulations against the plaintiff's contention that the dedication requirements included in the subdivision regulations amounted to taxation, thus violating the state constitution's guarantee of uniformity in taxation. The court drew the distinction between taxation and the regulatory power, held the subdivision regulation was within the latter, and permitted enforcement of the ordinance. Id. at 248,137 N.E.2d at 380 .

ss The due process distinction between taxing and licensing is questionable, because in either case the effect of city action is the same: non-city residents must pay without having had the opportunity to vote for the government which sets the level of payment.

If a license fee were set so high that it was clearly a revenue rather than a police matter, a court might declare the fee unconstitutional as an extraterritorial tax. But the question of when a license fee becomes a tax is not easily answered, as the opinion in City of Prichard v. Richardson, 245 Ala. 365, 17 So. 2d 451 (1944), demonstrates:

We have carefully examined the evidence both as to the amount of revenue derived from the ordinances and as to the cost and amount of regulation, fire, and police protection. . . . Suffice it to say that we conclude the trial court had the right to find that under this evidence the revenue exacted by the ordinances was all out of proportion to the cost of regulation and protection and therefore that the licenses imposed on businesses outside the city amounted to taxation for revenue. As demonstrated . . . such taxation is unconstitutional.

245 Ala. at 370, 17 So. 2d at 455. See also Town of Graysville v. Johnson, 33 Ala. App. 479, 34 So. $2 \mathrm{~d} 708$ (1948).

st 118 Tenn. 390, 103 S.W. 798 (1907).

ss The vehicle for these changes was an amendment to the Memphis city charter which named the new officers and enumerated their powers. Id. at 406-11, $103 \mathrm{~S}$.W. at 802-03. Among the powers delegated to the new city government were the power to abate nuisances 
tional doctrine. The court noted that, as a matter of necessity, a limited police power over "a small section" of the surrounding countryside could be granted in order to protect the city's residents from nuisances and health hazards. ${ }^{56}$ Such grants rest, the court stated, upon the theory that the municipality is the state's agent for the purpose of protecting the people of the state..$^{57}$ Nevertheless, the court held that the necessity justification for granting such powers defined its limits and could not conceive of any necessity for extending all the governmental or police powers extraterritorially or for extending such powers any great distance beyond the city boundaries. ${ }^{58}$

Thus, the single case invalidating extraterritorial government on due process grounds suggests only a limitation on its scope. Perhaps because of the vagueness of the "necessity" limitation, ${ }^{59}$ no case since Malone has held extramunicipal governance violative of due process. ${ }^{60}$

\section{Source of the New Challenge: Equal Protection}

The early substantive due process attacks on extraterritorial powers focused on the fact of their exercise. The modern Supreme

within ten miles of the city, id. at 416-17, $103 \mathrm{S.W}$. at 805 ; to establish quarantine zones in the same area, $i d$. at $419,103 \mathrm{S.W}$. at 805 ; to "prohibit . . . pigpens, cow stables, [and] dairies" within the corporate limits and for two miles beyond, id.; and to exercise "all governmental and police powers" within that area, id. at $420,103 \mathrm{~S}$.W. at 806 .

ss Id. at $420,103 \mathrm{~S} . \mathrm{W}$. at 806.

57 Id.

5s Id. at $420-21,103 \mathrm{S.W}$. at 806.

39 The Malone court found the ten-mile quarantine jurisdiction unobjectionable, id. at $419,103 \mathrm{~S}$.W. at $805-06$, but struck down the ten-mile jurisdiction over nuisances, $i d$. at 418 , 103 S.W. at 805; the two-mile jurisdiction over pigpens, cow stables, and dairies, $i d$. at 419 , $103 \mathrm{~S} . \mathrm{W}$. at 806 ; and the two-mile jurisdiction for the exercise of governmental and police powers, id. at $419-20,103 \mathrm{~S}$.W. at 806.

so One court indicated in dictum that it might find a grant of extraterritorial regulatory powers unconstitutional as a violation of due process. It managed, however, to put aside "the grave constitutional questions involved" and decide the case on the basis of statutory interpretation. Hollis v. Parkland Corp., 120 Tex. 531, 537, 40 S.W.2d 53, 56 (1931) (discussing a city's extraterritorial plat approval jurisdiction).

Other state courts have struck down grants of extraterritorial powers after Malone, but in each of these cases, the challenge was based on some idiosyncratic feature of the state's constitution rather than on due process grounds. See, e.g., Ball v. Peavey, 210 Ga. 575, 82 S.E.2d 143 (1954) (delegations of extraterritorial powers in city charters violate state constitution's provision that each legislative act must deal with only one subject clearly named in its title); Blair v. State, 90 Ga. 326, 17 S.E. 96 (1892) (same); Plath v. Hi-Ball Contractors, Inc., 139 Mont. 263, 362 P.2d 1021 (1961) (delegation of power to counties to zone outside city limits in cooperation with nearby cities violated Montana constitution, which denies legislative power to county governments). But see State v. Schroeder, 51 Iowa 197, 1 N.W. 431 (1879) (rejecting argument made in Ball and Blair). 
Court's foray into voting rights issues under the authority of the Equal Protection Clause, however, raises the question whether the exercise of such powers by elective entities unconstitutionally denies equal voting rights to affected non-residents.

\section{A. Extension of Equal Protection Voting Rights Doctrine to Municipal Entities}

Legislative distinctions among citizens for the purposes of voting rights are subject to the "strict scrutiny" test" ${ }^{61}$ of equal protection because, as the Court stated in Reynolds $v$. Sims, "The right to exercise the franchise in a free and unimpaired manner is preservative of other basic civil and political rights." ${ }_{63}$ The strict scrutiny test was initially employed in cases concerning voting rights in connection with state and federal elections. ${ }^{.4}$ In the 1968 case of Avery v. Midland County, ${ }^{65}$ the Court made it clear that local electoral laws are also subject to strict judicial scrutiny. Avery was an apportionment case in which residents of a county's only urban area complained that they were permitted to elect only two of the five members of the county's legislative organ ${ }^{b 8}$ even though the urban residents comprised about $95 \%$ of the county's population. The Court held that the Constitution does not permit local government units to vary substantially from equal population in electoral districting:

[I]t is now beyond question that a State's political subdivisions must comply with the Fourteenth Amendment. The actions of local government are the actions of the State. A city, town, or county may no more deny the equal protection of the laws than it may abridge freedom of speech . . . .

"For an explanation and criticism of the emergence of the "compelling state interest" or "strict scrutiny" test, see Shapiro v. Thompson, 394 U.S. 618, 655-63 (1969) (Harlan, J., dissenting); Karst \& Horowitz, Reitman v. Mulkey: A Telophase of Substantive Equal Protection, 1967 Sup. CT. REv. 39, 59-78.

¿2 377 U.S. 533 (1964).

"s Id. at 562. See also Wesberry v. Sanders, 376 U.S. 1, 17 (1963) (Black., J.) ("other rights, even the most basic, are illusory if the right to vote is undermined"); Gray v. Sanders, 372 U.S. 368, 380 (1963) (Douglas, J.) ("The idea that every voter is equal to every other voter . . . underlies many of our decisions").

"For examples of the earlier application of the strict scrutiny test to voter restrictions in state and federal elections, see Loving v. Virginia, 388 U.S. 1 (1967); Harper v. Virginia Bd. of Elections, 383 U.S. 663 (1966); Reynolds v. Sims, 377 U.S. 533 (1964).

is 390 U.S. 474 (1968).

"The county's legislative organ was composed of five members, one of whom was elected from the county at large. The other four members were chosen from the four districts, in one of which was located "virtually the entire city of Midland." 390 U.S. at 476. 
... [W]hen the state delegates lawmaking power to local government and provides for the election of local officials from districts specified by statute, ordinance, or local charter, it must insure that those qualified to vote have an equally effective voice in the election process. ${ }^{67}$

The Court in Avery emphatically rejected the argument that malapportionment at the local level was acceptable because countenanced by a properly apportioned state legislature, ${ }^{68}$ an argument akin to the "implied consent" theory used to justify extraterritorial delegations to municipalities. ${ }^{69}$ Given the quantum and importance of decisionmaking that takes place at the local level, the Court saw no significant difference, for equal protection purposes, "between the exercise of state power through legislatures and its exercise by elected officials in cities, towns, and counties."70

Avery applied the equal protection clause to condemn the dilution of votes in cases involving local governmental entities with general powers. After Avery the Court further extended the constitutional voting rights doctrine to cases of exclusion from the franchise and to cases in which the local unit possessed very limited governmental powers.

In Kramer v. Union Free School District No. $15^{71}$ the Court applied the Reynolds principle to a special purpose unit election and settled several important issues concerning the scope of constitutional electoral limitations. The plaintiffs in Kramer lived within the boundaries of the defendant school district, but were prevented by property requirements from voting in school board elections. Chief Justice Warren, writing for the Court, declared that the need for close judicial scrutiny of voter classifications is not affected simply because the political entity does not have "general" legislative powers: "Our exacting examination is not necessitated by the subject of the election; rather, it is required because some resident citizens are permitted to participate and some are not." 72 Thus, although the Court in Avery had hinted that special units not having "general governmental powers" might be permitted to deviate

${ }^{67}$ Id. at 480 (emphasis in original) (footnote omitted).

ss Id. at 481 .

see text and note at note 46 supra; Anderson, supra note 44, at 580-81; Bartelt, supra note 38, at 400-02; Becker, Municipal Boundaries and Zoning: Controlling Regional Land Development, 1966 WASH. U.L.Q. 1, 40 n.95; Bouwsma, supra note 46, at 814; Goodman, supra; note 46 , at 27 .

390 U.S. at 481 (footnote omitted).

71395 U.S. 621 (1969).

${ }^{72}$ Id. at 629. 
substantially from the one-man, one-vote ideal, ${ }^{73}$ Kramer holds that equal protection brooks no such limitation. Moreover, the Court stated, the need for strict scrutiny is not limited to apportionment statutes which may dilute citizens' votes; "[n]o less rigid an examination" is to be applied to classifications that deny the franchise. ${ }^{74}$ Lastly, the Court in Kramer resolved an issue that the decision-if not the logic-in Avery had left open and rejected the argument that the state was free to grant the voting privilege to whomever it pleased because the school board could have been appointed rather than elected. The constitutional problem, the Court responded, inheres not in the denial of the franchise but in differential treatment: "[O]nce the franchise is granted to the electorate, lines may not be drawn which are inconsistent with the equal protection clause of the Fourteenth Amendment."75

The Court in Kramer rejected the notion that the equal protection clause does not apply to local municipal enterprises which exercise less than full governmental powers, but left unclear the extent of the class of municipal activities subject to the fourteenth amendment "voting rights" doctrine. After Kramer, plaintiffs successfully attacked inequalities in voting rights in other types of special purpose districts. For example, Supreme Court decisions expanded the franchise in public utility bond issue referenda, ${ }^{76}$ and, in Hadley $v$. Junior College District, ${ }^{77}$ applied the one-person, one-vote rule to a junior college district. The Hadley Court, however, recognized that "there might be some case in which a State elects certain functionaries whose duties are so far removed from normal governmental activities and so disproportionately affect different groups"78 that the Reynolds principle would not apply. This nongovernmental/disproportionate impact limit was reached in the case of Salyer Land Co. v. Tulare Lake Basin Water Storage District. ${ }^{79}$ The Supreme Court in Salyer applied the standard suggested in Hadley

7390 U.S. at 485 .

74395 U.S. at 626.

${ }^{73}$ Id. at 629 (quoting Harper v. Virginia Bd. of Elections, 383 U.S. 663, 665 (1966)). See also Hadley v. Junior College Dist., 397 U.S. 50, 59 (1970). The Court has never indicated, however, that a state must create local governments by election rather than appointment.

" Cipriano v. City of Houma, 395 U.S. 701 (1969) (declaring unconstitutional a statute allowing only property owners to vote in municipal utility's referendum authorizing revenue bonds). See also City of Phoenix v. Kolodziejski, 399 U.S. 204 (1970) (extending Cipriano to municipal referendum authorizing issuance of general obligation bonds).

77397 U.S. 50 (1970).

78 Id. at 56 .

710 U.S. 719 (1973). See also Associated Enterprises v. Toltec Watershed Improvement Dist., 410 U.S. 743 (1973); Note, Property Qualifications for Voting in Special Purpose Districts: Beyond the Scope of "One Man-One Vote," 59 CoRnell L. REv. 687 (1974). 
and approved a property limitation upon the right to vote for directors of a water storage and supply district that disenfranchised numerous affected farmers.

\section{B. Evans v. Cornman: Geographical Classifications}

The Avery and Kramer line of cases involved claims by citizens residing within the geographic boundaries of the governmental entity. In the 1970 case of Evans v. Cornman ${ }^{80}$ the Supreme Court ruled that, under some circumstances, equal protection demands that a governmental entity extend voting rights to persons whom the entity does not characterize as "residents."

The plaintiffs in Cornman were residents of a federal compound within which the National Institutes of Health (NIH) were located. Although surrounded by Montgomery County, Maryland, the compound was subject to the jurisdiction of the federal government. The residents of the federal enclave paid no property taxes to the abutting local or county governments, although some sent their children to local public schools. When state election officials refused to register NIH residents to vote, on the ground that they were not "residents" of Maryland for purposes of its election laws, the residents secured a federal court injunction permitting them to vote.

On direct appeal the Supreme Court affirmed the district court's holding that the denial of the vote denied the NIH residents equal protection of the laws. Rejecting the argument that the NIH residents were not bona fide "residents" of Maryland for voting rights purposes, the Court applied the strict scrutiny test. ${ }^{81}$ In support of the franchise limitation the state asserted a justification that Kramer had suggested might suffice in some circumstances: "to insure that only those citizens who are primarily or substantially interested in or affected by electoral decisions have a voice in making them." ${ }^{83}$ In examining the articulated state interest, the Court cautioned that "such a claim cannot be lightly accepted. . . . All too often, lack of a 'substantial interest' might mean no more than a different interest ...." were affected by Maryland electoral decisions in a number of ways. Although federal courts had exclusive jurisdiction over the enclave,

80398 U.S. 419 (1970).

${ }^{81}$ Id. at $421-22$.

82395 U.S. at 631-33. "We need express no opinion as to whether the State in some circumstances might limit the exercise of the franchise to those 'primarily interested' or 'primarily affected." " Id. at 632.

3398 U.S. at 422.

${ }^{84}$ Id. at $422-23$ (citations omitted). 
the state's criminal laws were applicable by virtue of the Federal Assimilative Crimes Act. ${ }^{85}$ The residents had an interest in Maryland's spending and taxing decisions since Congress permits the states to levy and collect state taxes-with the exception of property taxes-on federal enclaves. ${ }^{86}$ Residents were also subject to state unemployment insurance and workmen's compensation laws, to state automobile registration requirements, to the process and jurisdiction of state courts, and to the family laws of the state. ${ }^{87}$ The differences of impact of state legislative decisions on Maryland residents and on enclave residents, the Court concluded, "do not come close to establishing that degree of disinterest in electoral decisions that might justify a total exclusion from the franchise." 88

Thus, although it remains true that citizens enjoy no inherent right to local self-government, ${ }^{88}$ it is now apparent that once elective government is established at the local level, all citizens affected by the exercise of governmental power in roughly equivalent degree have a right to whatever electoral franchise is granted. Voting rights distinctions among citizens on the basis of geographic boundaries are not justified unless the geographic exclusion reflects a significant difference in the extent of citizen interest in the unit's electoral decisions or is necessary to achieve some other compelling state interest.

\section{The Constitutionality of Delegations of Extraterritorial POWERS}

The validity of grants of extraterritorial powers to local governments has not been generally reconsidered. Recent state court cases challenging such powers have disregarded equal protection developments. ${ }^{90}$ The recent federal case of Little Thunder $v$. South Dakota, ${ }^{91}$ however, has applied the teachings of Kramer and

¿s The Federal Assimilative Crimes Act, 18 U.S.C. $\$ 13$ (1970), makes punishable that conduct within federal territorial jurisdiction, as defined by 18 U.S.C. $\$ 7$ (1970), that is not otherwise punishable under federal law, if the conduct "would be punishable if committed . . . within the jurisdiction of the State, Territory, Possession, or District in which such place is situated ...."

398 U.S. at 424.

s7 Id.

* Id. at 426.

3) "States do have latitude in determining whether certain public officials shall be selected by election or chosen by appointment and whether various questions shall be submitted to the voters." Kramer v. Union Free School Dist. No. 15, 395 U.S. 621, 629 (1969).

* See, e.g., City of Carbondale v. Van Natta, 61 Ill. 2d 483, 338 N.E.2d 19 (1975) (zoning regulation); State ex rel. Pat Griffin Co. v. City of Butte, 151 Mont. 546, 445 P.2d 739 (1968) (business regulation).

" 518 F.2d 1253 (8th Cir. 1975). 
Cornman to condemn the extension of full governmental control unaccompanied by extension of the franchise. The Little Thunder decision brings to the fore the question whether the exercise of more limited extraterritorial powers can survive equal protection scrutiny.

\section{A. Little Thunder}

Little Thunder involved a challenge to South Dakota statutes that provided for extraterritorial governance. Under South Dakota law, "unorganized counties"-designated geographical areas of the state that lack county governments-were subject to the jurisdiction of officials of a neighboring organized county ${ }^{92}$ Officials of the organized counties exercised considerable power over the unorganized counties. They could enact rural zoning regulations, control highway use, establish parks and libraries, supervise fiscal affairs, levy and collect taxes, and dispatch police with the power of arrest..$^{93}$ County legislative boards, sheriffs, auditors, treasurers, coroners, and prosecutors had full power over thousands of people in the unorganized areas. Residents of these areas, however, could not vote for county officials. ${ }^{94}$ Residents of the unorganized counties brought a class action in federal district court challenging the statutes that prevented them from voting. The district court rejected their claims and upheld the statutes.

On appeal the Eighth Circuit reversed, ruling that the district court had erred in applying the "rational basis" test to the residency requirements. Limitations on the franchise in elections "of general interest," the court held, are instead subject to the stringent "compelling state interest" test. ${ }^{95}$ Consistently with Cornman, the court peremptorily dismissed South Dakota's assertion that lack of residency alone furnished a sufficient state interest to justify denial of the vote ${ }^{96}$ and proceeded to test the geographic distinction for

32 S.D. COMpILED LAws ANN. \& 7-17-I (1967) (providing for "attachment" of unorganized counties to adjacent organized counties); S.D. Compiled LAws ANN. $\$ 7-17-3$ (1967) (granting county commissioners of organized counties all the powers in unorganized counties which they may ordinarily exercise in the county that elected them).

${ }^{93} 518$ F.2d at 1256-57.

"The disenfranchisement of the plaintiffs in county elections, required by S.D. ComPILED LAWS ANN. \$ 12-23-2 (1974), was explicit and almost complete. However, other statutes specifically authorized the plaintiffs to participate in the election of the county school board, S.D. Compiled Laws ANn. \$12-23-3 (1974), and highway officials, S.D. Compiled Laws ANN. $\$ 13-8-1$ (1974). They could also vote in all local, state, and federal elections. See 518 F.2d at $1254-55,1255$ n.3.

95 518 F.2d at 1255.

" The court noted the observation in Hill v. Stone, 421 U.S. 289, 297 (1975), that "any 
correlation with South Dakota's interest in excluding from the franchise insufficiently interested or affected voters. After canvassing the range of powers exercised by the organized counties over the citizens of the unorganized, the court easily concluded that the plaintiffs possessed a sufficiently substantial interest in the election of county officials. ${ }^{97}$ The state's final argument in justification, that the appellants were denied the vote only because they had not exercised their statutory right to organize county governments, ${ }^{98}$ was also easily dismissed; the plaintiffs' opportunity to form an organized county in the future, the court stated, "does not vitiate their present interest in their present county government" to a degree that justified exclusion from the vote. ${ }^{99}$ The court concluded that "although a state might constitutionally set up bona fide geographic lines as they relate to the organization of local government," it cannot use residency requirements to "disenfranchise citizens who have a substantial interest in the choice of who will function as their elected officials."

The Little Thunder decision confirms a point suggested by Kramer and Cornman: Where classifications for voting purposes are challenged, "citizen interest" analysis usually exhausts judicial inquiry. Although Cornman intimated that a limitation on the right to vote might be justified by a state interest other than that of denying the vote to citizens who are substantially less interested in or affected by electoral decisions than others, it is difficult to imagine what other state interests might be articulated. Indeed, the goal of limiting the franchise to citizens primarily interested in the electoral decision was the only state interest seriously considered in Kramer, Cornman, and Little Thunder.

classification restricting the franchise on grounds other than residence, age, and citizenship cannot stand unless the district or State can demonstrate that the classification serves a compelling state interest," yet treated the residence requirement as a classification to be closely scrutinized. The court relied on Cornman for the proposition that geographic residence limitations "must bear a close relationship to the underlying interest of the parties affected in the results of the elective process." 518 F.2d at 1256.

" 518 F.2d at 1256.

1s Under state law residents of unorganized counties could organize a county or attach themselves to an existing county, but only if one-half the voters were freeholders. S.D. ComPILED LAWS ANN. \$ 7-4-2 (1967). Since most of the residents of the unorganized counties were American Indians living on reservations, it was practically impossible for them to organize. The court suggested the statutory requirement was tantamount to property requirements that have been overturned by the Supreme Court. 518 F.2d at 1258 n.6.

"Id. at 1258.

${ }_{100}$ Id. at 1256 . 


\section{B. Exercises of Limited Extraterritorial Powers}

Only one equal protection challenge to the extraterritorial exercise of limited governmental powers by an elective unit has been decided by a federal court. That challenge was brought in Holt Civic Club v. City of Tuscaloosa. ${ }^{101}$ Residents of Holt, Alabama, an unincorporated community on the outskirts of Tuscaloosa, are, under two Alabama statutes, subject to the "police jurisdiction" of the abutting city, ${ }^{102}$ and, under another statute, to the city's power to license and regulate businesses. ${ }^{103}$ Residents of Holt brought suit in federal court seeking injunctive relief against continued enforcement of the state statutes, which, they argued, disenfranchised them in violation of the Constitution's equal protection guarantees. A three-judge district court granted the defendants' motion to dismiss, ruling that extraterritorial regulation is not "unconstitutional per se" under equal protection doctrine. ${ }^{104}$ The court distinguished Little Thunder on the curious ground that the plaintiffs were seeking not an extension of the franchise, as did the Little Thunder plaintiffs, but injunctive relief against extraterritorial regulation. ${ }^{105}$

The facts in Holt seem to provide the basis for an excellent test case. One statute contested in Holt delegates to cities the size of Tuscaloosa extraterritorial "police jurisdiction," 108 including the power to enforce "ordinances . . . enforcing police or sanitary regulations and prescribing fines and penalties for violation thereof

" 107 A second statute, uncontested in the Holt action, empowers Tuscaloosa to plan and control subdivisions within five miles of the city limits. ${ }^{108}$ Another statute vests the municipal court with jurisdiction in criminal matters ${ }^{109}$ arising in the city's police jurisdiction, and with the power to "impose the penalties prescribed by ordinance for the violation of ordinances and by-laws of the city"

${ }^{101}$ Civ. Action No. 73-M-736 (N.D. Ala. June 7, 1977) (three-judge district court), appeal docketed, No. 77-515 (U.S. 1977).

${ }^{102}$ ALA. CodE $\$ 11-40-10$ (1975) (conferring "police jurisdiction"), § 12-14-10 (1975) (conferring jurisdiction upon the municipal court), and $\$ 11-51-91$ (1975) (allowing the city to license businesses in its police jurisdiction). An Alabama court has interpreted the predecessor of $\$ 11-51-91$ as an amendment to $\$ 11-40-10$ which specifies some of the police powers available to the city for extraterritorial use. Town of Graysville v. Johnson, 33 Ala. App. 479, 34 So. $2 d 708$ (1948).

${ }^{103}$ Ala. Code \$11-51-91 (1975).

104 Holt Civic Club v. City of Tuscaloosa, Civ. Action No. 73-M-736 (N.D. Ala. June 7, 1977), appeal docketed, No. 77-515 (U.S. 1977).

ios Id.

108 Ala. COde \$ 11-40-10 (1975).

${ }^{107}$ Id.

${ }^{108}$ Ala. CODE $\$ 11-52-30$ (1975).

109 ALA. CODE \$ 12-14-10 (1975). 
occurring within the police jurisdiction. ${ }^{10}$ Yet another statute authorizes the Commission Board to "fix and collect licenses for any business, trade, or profession" within the police jurisdiction, although license fees for extraterritorial businesses are limited to onehalf the amount charged comparable in-city businesses."

The constitutionality of the exercise of such governmental powers over extraterritorials is a difficult question. As demonstrated above, the test is whether the denial of the vote is justified by a compelling state interest. The facts of Little Thunder presented a comparatively easy case because residents of South Dakota's unorganized counties were subject to the full governmental powers of the organized counties. Under the Alabama statutes involved in the Holt case, however, the extraterritorials are not subject to the full scope of municipal powers; the enfranchised residents of Tuscaloosa are subject to certain important governmental powers-such as taxation, ${ }^{112}$ eminent domain, ${ }^{113}$ and zoning $^{114}$ - that are not exercised beyond the city limits.

Whether residents of an area subject to the governmental powers of an elective local unit are so much less interested in the electoral decision, or, what is the same, sufficiently less affected by the powers of the local unit, to justify exclusion from the vote can perhaps be determined by comparing the interests at stake with those discussed in the Supreme Court's cases. The facts of Holt, for example, can be compared with the facts of Cornman. ${ }^{115}$ The factors which the Court in that case cited in support of its conclusion that the residents of the NIH enclave were substantially interested in state elections included the applicability of state criminal law, the amenability to the process of the state courts, the power of the state

110 ALA. CODE $\$ 12-14-1$ (b) (1975). The ordinances referred to are those enacted by the city's legislative body, the Commission Board, on which the residents of Holt are not represented.

"II ALA. Code \$ 11-51-91 (1975).

112 One power that can be exercised by a city government within its boundaries, the power to tax, is not exercisable extraterritorially. Municipalities are, however, entitled to collect "license taxes" in their extraterritorial jurisdictions. See text and note at note 51-53 supra. See also City of Prichard v. Richardson, 245 Ala. 365, 368, 17 So. 2d 451, 454 (1944) (distinguishing between use of license fees for revenue purposes, which is not permissible, and their use for regulatory purposes, which is); Atlantic Oil Co. v. Town of Steele, 283 Ala. 56, 58, 214 So. 2d 331, 333 (1968) (making same distinction).

i3 Ala. Code \& 18-1-1 (1975).

11 Although the terms "police and sanitary regulations" in ALA. CODE $\S 11-40-10$ (1975) might seem to permit extraterritorial zoning as an exercise of the police power, the Supreme Court of Alabama ruled in 1970 that the power to zone extraterritorially was not granted by the statute. Roberson v. City of Montgomery, 285 Ala. 421, 233 So. $2 \mathrm{~d} 69$ (1970).

II Evans v. Cornman, 398 U.S. 419, 426 (1970), discussed in text and notes at notes 80 88 supra. 
to regulate automobile use, and the power of the state to levy and collect taxes other than property taxes. ${ }^{116}$ The residents of Holt are subject to many analogous powers of the city of Tuscaloosa: the city's ordinances, ${ }^{117}$ the jurisdiction of its municipal court, ${ }^{118}$ and the several varieties of business licensing. ${ }^{119}$ On the whole, the Holt situation does not seem to present an imbalance of resident and non-resident interests any or much greater than that in the Cornman case. The only major distinction between the two cases is that the residents of the federal enclosure in Cornman, unlike the residents of Holt, were subject to some (though not all) tax burdens imposed on the residents of the contiguous entity. Relative financial stake, however, should not be a factor of overriding importance where excluded voters have other important interests. In Kramer the Court struck down a qualification for voting in school district elections based on real property holdings, ${ }^{120}$ even though the property tax was the only local source of school financing. ${ }^{121}$

118 Id. at 424.

17 ALA. CoDE \& 11-40-10 (1975).

118 AIA. CoDE \$ 12-14-1(b) (1975).

11 ALA. CODE \& 11-51-91 (1975).

${ }_{120}$ The statute challenged in Kramer, N.Y. Educ. Law $\$ 2012$ (McKinney 1969), now amended (Supp. 1976), provided that citizens of the United States, age twenty-one years or older, could vote in school district elections, if they either owned or leased, or were the spouse of an owner or lessee, of real property, or if they were the parent or guardian of a school-age child.

${ }^{121}$ Kramer v. Union Free School Dist. No. 15, 395 U.S. 621, 638 (1969) (Stewart, J., dissenting). The Court has recognized that greatly disproportional financial stake justifies limitations on the franchise expressed in terms of property qualifications in cases concerning the right to vote in special limited purpose district elections. Salyer Land Co. v. Tulare Lake Basin Water Storage Dist., 410 U.S. 719 (1973); Associated Enterprises, Inc. v. Toltec Watershed Improvement Dist., 410 U.S. 473 (1973). In both Salyer and Toltec, however, the Court majority applied the less stringent "rational basis" test because the entities involved did not perform "normal governmental activities"-an exception suggested by a dictum in the Hadley case. Salyer Land Co. v. Tulare Lake Basin Water Storage Dist., 410 U.S. 719, 72730 (1973).

The kinds of extraterritorial powers discussed in this comment, see Section II supra, apparently all fit within the category of "governmental" powers as defined by Supreme Court cases on voting rights. The extraterritorial powers granted municipalities more nearly resemble those found within the reach of the fourteenth amendment, such as operation of a school district, Kramer v. Union Free School Dist. No. 15, 395 U.S. 621 (1969), a junior college district, Hadley v. Junior College Dist., 397 U.S. 50 (1970), or a power company, Cipriano v. City of Houma, 395 U.S. 701 (1969); City of Phoenix v. Kolodziejski, 399 U.S. 204 (1970), than they resemble entities found to be without serious governmental powers, such as a water district, Sayler Land Co. v. Tulare Lake Basin Water Storage Dist., 410 U.S. 719 (1973); Associated Enterprises v. Toltec Watershed Improvement Dist., 410 U.S. 473 (1973), an advisory council of governments, Education/Instruccion, Inc. v. Moore, 503 F.2d 1187 (2d Cir. 1974), cert. denied, 419 U.S. 1109 (1975), an off-track betting corporation, Slisz v. Western Regional Off-Track Betting Corp., 382 F. Supp. 1231 (W.D.N.Y. 1974), or a retired teachers' pension plan, Tron v. Cordello, 427 F. Supp. 1175, 1190-92 (S.D.N.Y. 1976). 
Even in those cases in which the disparity of interest is very great, the denial of the franchise might nevertheless violate equal protection. For one thing, the Court has never unequivocally announced that the desire of a governmental unit of general powers to distinguish between classes of citizens on the basis of significant disparities in interest constitutes a compelling state interest. ${ }^{122}$ Moreover, cases such as Holt present a situation markedly unlike the cases the Court has faced. In cases such as Kramer and Salyer, involving the validity of property limitations on the right to vote in elections for special purpose entities, the crucial issue is whether the excluded citizens are sufficiently unaffected by the unit's discharge of its single function. In the case of extraterritorial powers, the disparity of interest derives from the unit's exercise of powers over residents that it does not exercise over extraterritorials. The extraterritorials, however, are as much affected by the specific powers exercised over them as are the residents of the municipality. It could be argued that even if the Constitution does not demand that extraterritorials have an equal voice in municipal elections, neither does it permit complete disenfranchisement on matters in which they have an interest equal to that of residents.

Cases such as Holt seem sufficiently like Cornman to warrant the conclusion that denial of the franchise denies equal protection of the laws. Less expansive grants of power over non-voting extraterritorials present the truly hard case. While an elective local government has a very strong and legitimate interest in denying an equal voice in its affairs to citizens who are unaffected by the bulk of the unit's actions and decisions, it does not follow that it has a compelling interest in governing residents of contiguous areas. The determination of that question instead turns on whether there exist alternatives to extraterritorial government that both protect the unincorporated area's residents' right to a voice in their governance and serve the state's interests in regulating unincorporated areas.

\section{Alternatives to Extraterritorial Government}

Examination of the alternatives to extraterritorial government is important for two reasons. First, as pointed out above, the availa-

122 The Court in Cornman said: "Without deciding the question we have assumed that [the interest in limiting the franchise to citizens primarily concerned] could be sufficiently compelling to justify limitations on the suffrage, at least with regard to some elections." 398 U.S. at 422. The Court has ruled that such an interest can afford a rational basis for voter classifications. Salyer Land Co. v. Tulare Lake Basin Water Storage Dist., 410 U.S. 719 (1973); Associated Enterprises, Inc. v. Toltec Watershed Improvement Dist., 410 U.S. 473 (1973). 
bility of feasible alternatives to present extraterritorial governance will be highly relevant in determining in any particular case whether the elective local government-or the state as its principal-has a compelling interest in denying the franchise to extraterritorials over whom it asserts limited governmental powers. Second, municipal governments whose exercise of extraterritorial powers violates equal protection may not desire, and indeed may not be constitutionally permitted, ${ }^{123}$ to extend full voting rights to extraterritorials.

Because of the wide variation in the extent and kinds of extraterritorial powers delegated, the question of how and whether the denial of representation can be remedied is not susceptible to any universal answer. The alternatives set forth below strike a middle ground between denying the vote to extramunicipal residents and extending them full voting rights in municipal elections.

\section{A. Reversion of Control over Unincorporated Areas to the State Legislature}

If existing statutes delegating extraterritorial control to cities were repealed or struck down, the delegated powers would automatically revert to the state legislature that originally granted them. The legislature could then enact laws replacing the city ordinances formerly applicable to these areas. Enforcement of these laws might, however, present serious problems. State police, who are

123 Indeed, recent federal cases suggest the interesting question of whether full enfranchisement of extraterritorials might violate equal protection. In several cases federal courts have faced the claim that overextension of the franchise denies "primarily interested" voters equal protection of the laws. In two such cases, the courts held that the franchise was not overinclusive, essentially because the challenged voters had an identifiable substantial interest in the government to be elected. Creel v. Freeman, 531 F.2d 286 (5th Cir. 1976), cert. denied, 97 S.Ct. 797 (1977) (upholding right of city dwellers to vote in elections for a separate county school board); Clark v. Town of Greenburgh, 436 F.2d 770 (2d Cir. 1971) (constitution of 5\% of town's tax base and other connections with the town gave county residents too substantial a interest to permit disenfranchisement). In Locklear v. North Carolina State Bd. of Elections, 514 F.2d 1152 (4th Cir. 1975), however, the court held that allowing city residents to vote for the county school board unconstitutionally diluted the votes of non-city residents, because the interests of the city residents resulted largely from non-mandatory contracts between the county and city boards. The court found no "compelling state interest" to justify the state's dilution of county voters. Id. at 1155. It is interesting to speculate what standard the court would have applied if the situation were reversed; if the city voters were denied the franchise and sued to have their right to vote recognized. Wherever one group's vote is not "diluted," the other group's vote is denied. In Creel v. Freeman, 53I F.2d 286 (5th Cir. 1976), cert. denied, 97 S.Ct. 797 (1977), the court found that the alleged "dilution" of the vote was not "irrational" or "wholly irrelevant," $i d$. at 288 , but that the proposed denial of the vote to city dwellers might not satisfy the "compelling state interest" standard. Id. The Creel court, however, explained the different result in Locklear on the basis of factual differences. Id. at 289. 
ordinarily charged with enforcement of state laws, would be hard pressed to enforce new state laws dealing with particular ills that require almost constant supervision. Enforcement of regulations on zoning, disorderly conduct, and refuse disposal, for example, might be practically impossible unless state police were permanently assigned to unincorporated areas for just those purposes. This could impose considerable financial burdens on states where much land remains unincorporated.

Reversion of control to state legislatures would also diminish the possibility of direct cooperation between cities and adjacent unincorporated territory. Both regions may suffer because of a lack of coordinated control over contiguous areas. Zoning and sanitary regulations governing the city's outer edge, for example, might be rendered virtually worthless if the activities they seek to regulate or forbid were permitted directly across city lines on unincorporated land. If the legislature chose to regulate such matters in unincorporated areas, city representatives would have to negotiate with state officials lacking familiarity with local conditions. Moreover, the costs of negotiating on such particulars with representatives of every city adjoining an unincorporated area might prove prohibitive.

In spite of these disadvantages, reversion of control to the legislature may be a desirable option. Although this approach might amount to no practical control, an absence of control may be unobjectionable in some situations. If, as one commentator suggests, extraterritorial powers are rarely used, ${ }^{124}$ it could be they are not needed at all. Some types of extramunicipal regulation, such as zoning and subdivision controls, might simply be unnecessary beyond municipal boundaries. Other types of controls can be effected by state law and enforced by municipal police. ${ }^{125}$ Such a scheme would not violate the fourteenth amendment since the local police would be acting in the place of state police. Their duties would be administrative and not legislative in nature.

Reliance on the residual power of the legislature to control otherwise ungoverned areas would entail the creation of no special bureaucracy and the taking of no irreversible steps. This lack-ofcontrol option is especially viable in states where developing exurban areas can be annexed easily and thus subjected to city zoning

${ }^{125}$ F. Sengstock, Extraterritorial Powers in the Municipal Area $65-66$ (1962).

125 Statutes of this kind are in force in North Carolina, Tennessee, and Virginia. N.C. Gen. Stat. § 160A-286 (1976); Tenn. Code AnN. § 6-609 (1971); VA. Code § 19.2-250 (1975). See Kelley v. County of Brunswick, 200 Va. 45, 104 S.E.2d 7 (1958) (explaining the Virginia statute's purposes and effects). 
and subdivision regulations as necessary. ${ }^{126}$ It also could serve as a starting point from which other alternatives could be implemented as needed.

\section{B. Active Management by State Officials}

A state may exercise its authority over unincorporated areas through an appointed body or individual. ${ }^{127}$ Such an official or board would not be subject to undue influence by city (as opposed to noncity) residents and could therefore effectuate the state's legitimate interests, such as assuring compatibility of city and extracity regulations on certain subjects, while protecting extramunicipal residents from the excessive demands of city interests.

Such a system has been used in Vermont since 1862. ${ }^{128}$ Under the Vermont statutes, the governor every two years appoints a "supervisor" for all gores (unincorporated regions) in each county. The supervisor collects state taxes and performs general governmental functions. ${ }^{129}$ The supervisor is also empowered to appoint a planning commission for all the gores in his county. ${ }^{130}$ This scheme, which would permit planning, subdivision approval, and zoning for unincorporated areas, presents no constitutional difficulties. The concept might even be extended so that other services, such as police and fire protection, would be provided. The Vermont plan could be used without cost to the state, because it provides for a method of local tax assessment and collection and thus allows exurban residents to assume the financial burdens of their own government. ${ }^{131}$ Adoption of the plan would remove a financial burden from city governments that perform extraterritorial chores yet cannot collect corresponding taxes. ${ }^{132}$

${ }_{126}$ This is not to suggest, however, that current state laws on annexation or merger are free from fourteenth amendment problems. On this subject, see Hagman \& Disco, One-Man One-Vote as a Constitutional Imperative for Needed Reform of Incorporation and Boundary Change Laws, 2 Urban Law. 459 (1970). See also Kelley v. Mayor and Council, 314 A.2d 208 (Del. Ch. 1973), aff'd, 327 A.2d 749 (Del. 1974) (invalidating a municipal annexation of unincorporated land because a statutory voting scheme violated the fourteenth amendment's equal protection clause).

${ }_{127}$ If neither municipal residents nor extraterritorials were permitted to vote on matters that concerned the latter there could be no equal protection objections to the arrangement.

${ }^{22 \times}$ VT. STAT. ANN. tit. 24, $\$ \$ 1401-1409$ (1975).

${ }^{129}$ Id.

${ }^{130}$ Id. $\S 4327(\mathrm{e})$.

131 In collecting taxes, the Vermont supervisor cooperates with appraisers appointed by the state tax commissioner, subject to gubernatorial approval. Id. $\S \S 1402,1406-08$.

${ }_{132}$ Statutes authorizing cities to exercise powers beyond their limits almost universally fail to allow taxation to support that exercise. The exceptions to this general rule pertain to licensing and regulating extramunicipal businesses. See, e.g., Mont. Rev. Codes ANN. § 11 - 
One of the major purposes of extraterritorial delegationsensuring compatible land use through extraterritorial zoning and subdivision-could also be achieved. Although the Vermont statutes do not require such cooperation, the goal of uniform development could be incorporated into statute, leaving the degree and manner of cooperation to the officials involved. Alternatively, the statute could require supervisors of unincorporated areas to consult officials of nearby cities, and vice versa, in making zoning and subdivision plans. ${ }^{133}$ As a third route to achieving compatible land uses, the statute could allow neighboring governments (whether or not incorporated) to appear as parties in interest during the consideration and appeal of zoning and subdivision plans. ${ }^{134}$

\section{Active Management at the County Level}

Just as a fairly apportioned state legislature can constitutionally govern unincorporated areas directly, so can an elected, fairly apportioned county legislature. If a state has an operating network of county governments, ${ }^{135}$ use of county government to manage unincorporated areas may be a more desirable alternative than direct government by the state legislature because of the latter's remoteness from local problems and the relative unimportance to the state of purely local issues. Several states have already delegated to county governments authority of the type ordinarily delegated to cities. ${ }^{136}$ Maryland, for example, authorizes some counties to estab-

918 (1968); White v. City of Decatur, 225 Ala. 646, 144 So. 873 (1932) (interpreting the predecessor of AlA. CODE \& 11-51-91 (1975)). Apparently, however, at least one state has allowed its cities to collect fees as a precedent to plat approval, despite the absence of an explicit statutory authorization to do so. The extent to which other states allow this, or would allow it, is unclear. See Prudential Co-operative Realty Co. v. City of Youngstown, 118 Ohio St. 204, 160 N.E. 695 (1928) (allowing collection of such fees of $\$ 5$ or less; if fees were greatly in excess of inspection costs, they would be invalid as excise taxes). But cf. Newport Building Corp. v. City of Santa Ana, 210 Cal. App. 2d 771, 26 Cal. Rptr. 797 (1962); Sanchez v. City of Santa Fe, 82 N.M. 322, 481 P.2d 401 (1971); National Realty Corp. v. City of Virginia Beach, 209 Va. 172, 163 S.E.2d 154 (1968) (all denying the cities' authority to collect a fee as a condition precedent to plat approval, even when the platted land is located within the city).

133 An approach similar to that suggested is used in California. See Car. Gov'T CoDE $\S$ 66453 (West Supp. 1977).

13 In Rhode Island, neighboring municipalities are permitted to appear as parties in interest in any proceeding concerning the adoption or amendment of a zoning ordinance which will affect land on which the two abut. Such municipalities are given the same standing and rights as a landowner located within the amending or adopting municipality. R.I. GEN. LAWS $\$ 45-24-4.2$ (1970).

135 Vermont has no county level of government.

is See, e.g., ArIz. Rev. Stat. $\$ 11-251$ (Supp. 1977) (adopt health and police regulations); Cal. Bus. \& Prof. Code $\$ 16100$ (West 1964) (license businesses); GA. CoDE $\S 23-1401$ (1975) (appoint police); IOWA CODE ANN. \$332.3 (West 1977) (inter alia, catch dogs, establish a 
lish and operate a police force, abate nuisances, control refuse disposal, and issue plumbing, zoning and building permits and regulations. ${ }^{137}$ Such powers could be delegated to county governments only for unincorporated areas, rather than for the entire county as the Maryland statute provides. ${ }^{138}$

Indiana provides another model of county governance. That state empowers county advisory planning commissions to serve the city as well, at the discretion of the city council. ${ }^{139}$ Under a similar type of plan, a city could permit the county to exercise governmental power over it to the extent that it sees uniformity of regulation in any particular area as desirable. For example, a city might allow county governments to prescribe zoning regulations, while retaining jurisdiction for all other purposes. ${ }^{140}$

\section{Management by Special Purpose Government}

In states where county governments do not exist or in situations where the need for civic cooperation transcends county as well as city lines, creation of a special governmental unit by the state legislature may be the preferred alternative. One current example of a multi-purpose special government is the Boston area's Metropolitan District Commission (MDC). Under the Boston plan, the governor of Massachusetts appoints commissioners who have jurisdiction for various limited purposes over a number of municipalities in the greater Boston area. ${ }^{141}$ The MDC performs several governmental functions. It exercises the power of eminent domain, operates a

building code, maintain and improve cemeteries); Miss. CoDE ANN. $\S 19-3-41$ (1972) (regulate use and sale of fireworks).

137 MD. ANn. Code art. 25, § 3 (1973).

${ }_{135}$ If the county governments performed governmental functions only in unincorporated areas, such a delegation might be constitutionally infirm were city residents allowed to vote in county elections. Conversely, if the county government performed governmental functions in both cities and unincorporated areas, it might be impermissible not to allow city residents to vote in county elections. See note 123 supra. However, it can be said with assurance that it would not violate the fourteenth amendment if only residents of unincorporated areas voted in county elections and the county government so elected performed governmental functions only in the unincorporated areas; similarly, it would be permissible to allow both city residents and residents of unincorporated areas to vote in county elections if the county government performed the same governmental functions in the city and unincorporated areas.

${ }_{138}$ IND. Code ANN. $\$ 18-7-5-25$ (Burns 1974).

${ }_{110}$ Given the apparent preoccupation of some states with cemetery regulation, see text and notes at notes 24-27 supra, it may be worth drawing special attention to the Maine statute designed to deal with this problem. It charges county commissioners with responsibility for maintaining cemeteries in unincorporated areas. ME. Rev. STAT. tit. 13, 11103 (1974). Presumably these responsibilities could be enlarged to include whatever other kinds of regulation a state considered necessary.

"I Mass. ANw. Laws ch. 28, $\$ 1$ (Michie/Law. Co-op Supp. 1975); id. ch. 92. 
police force with limited powers, and regulates water, sewage, and recreation facilities. ${ }^{142} \mathrm{~A}$ special government district modeled on the MDC might exercise police, sanitary, zoning, and subdivision authority in a number of towns and unincorporated areas. Its commissioner could be elected by the people served or, as in the Boston example, appointed by the governor.

Although such a unit might effect a saving of funds through consolidation of the efforts of several communities, the reasons for its use would have to be sufficiently compelling to justify the establishment of an entirely new governmental structure. In many areas low population density and lack of industrial or commercial development in unincorporated areas make such a concept an unrealistic and expensive alternative. Furthermore, since any such special purpose government would have to be empowered to lay and collect its own taxes, ${ }^{143}$ this alternative would be feasible only where there exists a relatively even distribution of taxable resources in the area to be governed; otherwise, the residents of the municipality would likely bear a disproportionately heavy tax burden.

A less ambitious form of special purpose government for zoning and subdivision control is the area planning commission used in Indiana. ${ }^{144}$ The Indiana scheme provides for state appointment of an area-wide advisory commission. The commission develops a unified plan for regional development, including zoning ordinances. Costs of such a planning commission might be defrayed by populationbased contributions from the participating governments. ${ }^{1+5}$ While this plan relies upon voluntary municipal cooperation and therefore cannot assure adequately controlled development throughout the district, it may provide a means of guiding development in a rural area or in an area centered around a single small city where no effective general-purpose county government exists.

\section{E. Management at the Local Level}

As a final alternative to extraterritorial delegation of municipal power, unincorporated areas could be permitted to govern themselves, at least in some matters. New Hampshire grants this power

112 Id.

is The MDC collects assessments from its participating municipalities based on the amount of services rendered. See Mass. ANs. LAws ch. 92, §§ 1A, 5, 5A, 5B, 6, 7, 8 (Michie/Law. Co.op, 1975, as amended, Supp. 1976); id. $\$ \S 26,58,59,59 \mathrm{~A}$ (1975).

"' IND. Code ANN. \$\$ 18-7-4-1-99 (Burns 1974).

is Indiana law requires county participation as a condition precedent to the formation of such a commission. IND. CODE ANN. $\$ 18-7-4-6$ (Burns 1974). The county government then pays all commission expenses. Id. at $\$ 18-7-4-29$. 
to unincorporated areas. ${ }^{146}$ Perhaps government by the citizenry of such an entity might produce some rudimentary form of police protection; ${ }^{147}$ in all likelihood, however, were residents of an unincorporated area numerous or interested enough to pass and enforce police, sanitary, zoning and subdivision regulations, they would incorporate and do so.

\section{CoNCLUSION}

Modern equal protection developments suggest that the exercise of extraterritorial powers by elective local government units may be constitutionally infirm. Local voter classifications, including geographic classifications, must be evaluated under the strict scrutiny test. Thus, the legitimacy of a voter classification turns on whether the interest of excluded citizens in a unit's electoral decisions is so insubstantial in comparison with that of the included citizens that the classification can be said to promote a compelling state interest. Applying this test, a court of appeals in Little Thunder v. South Dakota struck down South Dakota statutes which granted organized counties extensive governmental powers over unorganized counties. Extraterritorial extensions of full police power, as authorized, for example, in Idaho and North Dakota, are virtually indistinguishable from the arrangements condemned in Little Thunder.

Most delegations of extraterritorial power, however, are far more limited. In many cases in which municipalities exercise something less than the full police power extraterritorially, the comparative insubstantiality of impact on extraterritorials might justify the refusal to extend the full franchise. The disparity of interest argument should not, however, conclude the equal protection inquiry. No Supreme Court case answers the question whether a voter classification tailored to reflect a substantial disparity of citizen interest can survive equal protection scrutiny where the classification results in denying any voice to voting-age citizens permanently subject to the exercise of some governmental power by an elective local unit. Under the strict scrutiny standard, the constitutionality of such arrangements should turn on the availability of alternatives to complete disenfranchisement.

This comment has outlined a number of alternatives to extraterritorial government. Each alternative has its strengths and weak-

14 N.H. Rev. Stat. ANN. \$\$ 53:1-7 (1970).

${ }_{117}$ See id. at $\$ \$ 53: 2-6$. 
nesses; none will suit every situation. Nevertheless, a state or locality probably can combine features of the various alternatives in order to fashion a suitable means of governing areas now subject to various forms of control by contiguous municipalities. If this is so, all but de minimis forms of extraterritorial control are in danger of invalidation.

David E. Hunt 